UDC: $615.454 .2: 612.063$

DOI: $10.15587 / 2519-4852.2020 .197347$

\title{
RESEARCH OF MEDICAL TREATMENT INFLUENCE OF "MELANIZOL" SUPPOSITORIES ON BACKGROUND OF "MECHANICAL" VAGINITIS IN RATS
}

\author{
O. Dolzhykova, L. Maloshtan
}

\begin{abstract}
Мета. Дослідження лікувального впливу нових вагінальних супозиторіїв «Меланізол» на основі метронідазолу та олії чайного дерева на моделі «механічного» вагініту у шурів-самиць.

Методи. Лікувальну дію супозиторїв «Меланізол» вивчали у шурів-самиць на моделі «механічного» вагініту, який є вагінітом з вторинним обсіменінням. На тлі вагініту досліджували загальний стан тварин, динаміку маси тіла, морфологічного складу периферичної крові та швидкість зсідання еритроцитів, зміни показника рН та температури у піхві щурів, також макроскопічно оцінювали зміни слизової оболонки піхви.
\end{abstract}

Результати. Результати досліджень свідчать, щуо на тлі патологї розвивались зрушення, які проявлялися виразним набряком м'яких тканин навколо піхви, зниженням маси тіла, зрушенням рН у лужний бік, підвищенням температури у піхві, лейкоцчитозом, зсувом лейкочуитарної формули у бік підвищення кількості нейтрофілів, підвищенням швидкості седементащії еритроцитів. 3 боку слизової оболонки піхви спостерігали ураження, які проявлялися набряком, гіперемією і чисельними геморагіями. За умов лікування супозиторіями «Меланізол» спостерігали достовірне відновлення показника рН та зниження температури у піхві тварин, зниження швидкості зсідання еритроцитів, загальної кількості лейкоцитів та відновлення рівня нейтрофілів відносно до показників групи інтактних тварин. Макроскопічні дослідження слизової оболонки піхви продемонстрували лікувальний ефект вагінальних супозитрїв «Меланізол». Це проявлялося достовірними зменшенням площі ураженої ділянки піхви та проявів ї̈ ураження. $3 а$ ефективністю супозиторії «Меланізолт» достовірно перевищували препарат порівняння «Гравагін» та не поступалися референс-препарату «Супозиторії з обліпиховою олією».

Висновки. Доведено лікувальний вплив нових вагінальних супозиторіїв «Меланізол» на основі метронідазолу та олії чайного дерева на моделі «механічного» вагініту у шурів-самиць. Досліджувані супозиторії «Меланізол» є перспективним лікарськими засобом для лікування неспециифічних вагінітів, викликаних механічним подразником і потребують проведення подальших досліджень у зазначеному напрямку.

Ключові слова: експериментальний вагініт, супозиторії вагінальні, метронідазол, олія чайного дерева, щури.

Copyright (C) 2020, O. Dolzhykova, L. Maloshtan This is an open access article under the CC BY license (http://creativecommons.org/licenses/by/4.0).

\section{Introduction}

For a long time inflammatory diseases of the lower genital tract (IDLGT) are dominant in the structure of gynecological pathology. Particular attention to them is due to the impact on women's reproductive function [1].

The cause of IDLGT is often the microbial flora, which is represented by conditionally pathogenic microorganisms and pathogens of a specific infection [1,2]. Today, non-specific infectious of IDLGT, are named vaginitis and found in a wide age range. The development of these diseases is caused by the interaction of microorganisms with immunobiological components of the body, as well as the state of the female genital organs [1]. The literature indicates that the main causes of nonspecific vaginitis (NV), are infectious diseases, endocrine pathology, decreased ovarian function, the action of various local damaging factors (constant syringes, the introduction of chemical contraceptives in the vagina, etc.), as a rule, to cause the integrity of the mucous barriers of the vaginal epithelium and increase the susceptibility to infection [1-3].
Questions of treatment of patients with NV to date remain debatable, since the response of the body to the intervention of the pathogen depends on a number of circumstances, which are determined by its individual characteristics. The polyetiology and variability of NV agents dictate the need for periodic therapy review [4]. Many medical schemes that are used to treat NV, testifies to their low therapeutic efficacy. Prolonged antibacterial treatment of chronic NV changes the endogenous microflora, causing an increase in the number of antibacterial strains resistant to action. That is why most researchers play a major role in the local treatment of vulvovaginitis. The advantages of topical treatment are minimal risk of adverse reactions, simplicity and ease of use, in the absence of contraindications (except for individual intolerance of the drug) and the possibility of use in extragenital pathology [3].

Therefore, our aim was to study the therapeutic influence of new vaginal suppositories "Melanizol" based on metronidazole and tea tree oil on the model of "mechanical" vaginitis in female rats. 


\section{Planning (methodology) of research}

The aim was to investigate the healing properties of "Melanizol" suppositories, developed by the staff of the Department of Technology of Drugs of NUPh under the guidance of prof. Yarnykh T.G. It contains $250 \mathrm{mg}$ of metronidazolum, $100 \mathrm{mg}$ of tea tree oil, the mixture of PEO-1500 and PEO-400 (9:1) [5]. On the pharmaceutical market of Ukraine, drugs that are presented for the treatment of NV [6] have both advantages and numerous side properties. In previous studies, we have found that suppositories of "Melanizol" show expressive anti-inflammatory [7] and antimicrobial [8] effect. These properties have led to the feasibility of experimental studies of suppositories "Melanizol" as a treatment for vaginitis.

Vaginal suppositories "Gravagin" (product of "Sperco Ukraine", Ukraine; 1 suppository contains 500 mg of metronidazolum) was comparison drug because it is used for the treatment of bacterial infectious diseases of the genitals and Hippophaes oleum suppositories (unpatented denamination, product of "Nizhpharm", Russia; 1 suppository contains $500 \mathrm{mg}$ of oleum Hippophaes) was comparison drug because it is used in gynecology for the treatment of vaginitis, endocervicitis, cervical erosion.

\section{Materials and methods}

Therapeutic effect of suppositories "Melanizol" was studied on the model of "mechanical" vaginitis in rats-females weighing 180-220 г [9]. This type of vaginitis is vaginitis with the attachment of an infectious agent. In connection with the classification of non-specific vaginitis, a "mechanical" vaginitis was modelled, which provides for secondary insemination by bacterial microflora and increased growth of saprophytic microflora, which leads to the development of bacterial vaginitis by a mechanism close to infectious and, as a rule, changes in $\mathrm{pH}$ and temperature $\left(\mathrm{t}^{\circ} \mathrm{C}\right)$ in the vagina.

Animals for the experiment were selected based on the phase of the estrous cycle. Before testing and one day before the administration of the test drugs, the animals were examined to assess their health status. The animals were kept on a standard diet of the vivarium. Care of them (including euthanasia) during the experiment was carried out according to the available documents, which regulate organization of the work using experimental animals. The principles of the "European Convention for the Protection of Vertebrate Animals used for experimental and other scientific purposes" were observed (Strasbourg, 18.3.1986) [10].

The animals were divided into 5 groups ( 7 rats in each group) as follows:

group 1 - intact animals (IC, no pathology);

group 2 - control pathology (PC, positive control);

group 3 - animals treated with vaginal suppositories "Melanizol" (CP+Melanizol);

group 4 - animals treated with the reference drug "Hippophaes oleum suppositories" (CP+Hippophaes); group 5 - animals treated with the reference drug, vaginal suppository "Gravagin" (CP+Gravagin).

The studied suppositories and reference drugs were injected vaginally once a day at doses calculated using the specific sustainability factors by Y.R. Rybolovliev, applied in the experimental pharmacology [11].
The criteria for the severity of vaginitis were the general condition of the animals, the dynamics of body weight, which was studied on the $6^{\text {th }}$ (peak of pathology) and $11^{\text {th }}$ (end of treatment) days of the experiment. On the $11^{\text {th }}$ day of the experiment, animals were decapitated under mild ether anesthesia and macroscopically evaluated changes in vaginal mucosa (VM) according to three parameters: edema, hyperemia, hemorrhage in points, and the percentage ratio of the area of the affected area of the vagina $(\mathrm{mm})$ to the area of vagina $(\mathrm{mm})$ [9].

In order to determine in more detail the expressiveness of the inflammatory process under the influence of the studied agents on the $11^{\text {th }}$ day of the experiment, the indicators of morphological composition of peripheral blood were assessed: hemoglobin level, total leukocyte and erythrocyte count, leukocyte formula and erythrocyte sedimentation rate (ESR) [12]. The course of the pathology was also evaluated by indicators $\mathrm{pH}$ (was performed using the indicator test strips "pH-test" (Limited Liability Company "Norma", Ukraine) and $\mathrm{t}^{\circ} \mathrm{C}$ (Electrothermometer "Microlife", Switzerland) in the vagina.

Statistical treatment of the obtained results was carried out with the program "Excel", using parametric Neuman-Keuls and non-parametric criteria U-test MannWhitney-Wilcoxon. The differences were considered statistically significant at $\mathrm{p} \leq 0.05$.

\section{Results}

The data characterizing the effect of the studied suppositories of "Melanizol" and reference drugs on the severity of "mechanical" vaginitis were observed in Tables $1-3$.

The results show that mechanical damage to the $\mathrm{VM}$ of rats within 5 days leads to the development of experimental vaginitis. Thus, the symptoms of VM inflammation in CP group animals were manifested by a clear swelling of the soft tissues around the vagina. The presence of pathology is evidenced by the dynamics of body mass of animals of the CP group (Table 1), which significantly decreased in the initial data by the $6^{\text {th }}$ day after the last mechanical scarification - by $4.5 \%$ and by the $11^{\text {th }}$ day - by $6.5 \%$, as well as the shift of the $\mathrm{pH}$ to the alkaline side and an increase in the temperature in the vagina (Table 2). Treatment of vaginitis with the studied suppositories "Melanizol" and the "Hippophaes oleum suppositories" significantly reduced the inflammation symptoms in animals. On the $11^{\text {th }}$ day of the experiment in the group of animals treated with suppositories of "Melanizol" and "Hippophaes oleum suppositories" effects of inflammation of tissues around the vagina were not observed. At the same time, in rats using suppositories of "Gravagin", the signs of the inflammatory process remained somewhat, but had significantly less pronounced signs compared to the $\mathrm{CP}$ group of animals.

The integral indicator of the experimental animals body weight was likely to increase with respect to the $\mathrm{CP}$ group and did not have significant fluctuations compared to the initial data throughout the experiment (Table 1). Against the background of pathology, the body weight of the animals decreased and the reference drug suppositories of "Gravagin" only for $11^{\text {th }}$ days significantly improved this indicator, which by the end of the experiment did not reach the original data. 
Table 1

Dynamics of body weight of rats on the background of "mechanical" vaginitis and under the conditions of pharmacological correction $\left(n=7, x \pm S_{x}\right)$

\begin{tabular}{|l|c|c|c|}
\hline \multirow{2}{*}{ The conditions of the experiment } & \multicolumn{3}{|c|}{ Body weight of rats, $\mathrm{g}$} \\
\cline { 2 - 4 } & Output data & $6^{\text {th }}$ day & $11^{\text {th }}$ day \\
\hline IC & $204.45 \pm 3.34$ & $208.35 \pm 3.28$ & $210.68 \pm 4.35$ \\
\hline CP & $205.83 \pm 2.57$ & $193.83 \pm 1.30^{*}$ & $188.83 \pm 1.74 *$ \\
\hline CP+Melanizol & $203.00 \pm 2.31$ & $202.50 \pm 2.13^{* *}$ & $203.33 \pm 2.11^{* *}$ \\
\hline CP+Gravagin & $201.33 \pm 2.31$ & $195.50 \pm 2.14^{*}$ & $197.83 \pm 2.09 * / * *$ \\
\hline CP+Hippophaes & $207.17 \pm 2.24$ & $204.17 \pm 1.68^{* *}$ & $204.83 \pm 1.54 * *$ \\
\hline
\end{tabular}

Note: $*$ - significant in relation to output data $(p \leq 0.05) ; * *-$ significant in relation to control pathology $(p \leq 0.05)$

The presence of systemic disorders on the background of "mechanical" vaginitis was reflected in changes in hematological parameters (Table 2).

In the CP group of animals on the $11^{\text {th }}$ day of the experiment observed an expressed inflammatory reaction, which indicates a significant increase in the number of leukocytes in the IC group, ESR and changes in the leukocyte formula, which were manifested by an increase in the number of neutrophils and monocytes (Table 2).
A significant decrease in hemoglobin and erythrocyte counts against inflammation due to significant damage to the VM by the scarifier is significant for the IC group.

The results of the study of hematological parameters, namely a significant decrease in the number of neutrophils for the $11^{\text {th }}$ day of the experiment in the group $\mathrm{CP}+$ Melanizol, indicate the suppression of inflammation of VM.

Table 2

Changes in hematological parameters, $\mathrm{pH}$ and $\mathrm{t}^{\circ} \mathrm{C}$ in rats on the model of "mechanical" vaginitis and under the conditions of pharmacological correction on the $11^{\text {th }}$ day of the experiment $\left(n=7, x \pm S_{x}\right)$

\begin{tabular}{|l|c|c|c|c|c|}
\hline \multicolumn{1}{|c|}{ Indicator } & IC & CP & CP+Melanizol & CP+Hippophaes & CP+Gravagin \\
\hline Hemoglobin, g/l & $117.55 \pm 1.53$ & $113.40 \pm 2.35^{*}$ & $116.56 \pm 2.23$ & $114.35 \pm 3.24$ & $113.60 \pm 1.25$ \\
\hline Erythrocytes, $10^{12} / 1$ & $4.25 \pm 0.15$ & $3.96 \pm 0.14^{*}$ & $4.12 \pm 0.96^{* *}$ & $3.97 \pm 0.14$ & $3.64 \pm 0.15$ \\
\hline Leukocytes, $10^{9} / 1$ & $8.55 \pm 0.24$ & $13.68 \pm 0.34^{*}$ & $9.68 \pm 0.38^{*} / * * / * * *$ & $9.98 \pm 0.17 * / * *$ & $10.94 \pm 0.35^{*}$ \\
\hline \multicolumn{7}{|c|}{ Leucocyte formula, \% } \\
\hline Neutrophils & $27.64 \pm 0.54$ & $35.00 \pm 0.63^{*}$ & $29.62 \pm 0.37 * / * / * * *$ & $29.75 \pm 0.25^{*} / * *$ & $33.53 \pm 0.27^{*}$ \\
\hline Eosinophils & $1.75 \pm 0.16$ & $2.13 \pm 0.23$ & $1.62 \pm 0.26$ & $1.87 \pm 0.23$ & $1.25 \pm 0.21$ \\
\hline Lymphocytes & $68.13 \pm 0.79$ & $58.00 \pm 0.73^{*}$ & $65.00 \pm 0.57^{*} / * *$ & $64.37 \pm 0.49^{*} / * *$ & $62.17 \pm 0.39^{*} / * *$ \\
\hline Monocytes & $2.75 \pm 0.31$ & $4.87 \pm 0.29^{*}$ & $3.75 \pm 0.25 * / * *$ & $4.00 \pm 0.19^{*}$ & $4.00 \pm 0.15^{*}$ \\
\hline $\mathrm{ESR}, \mathrm{mm} / \mathrm{h}$ & $2.25 \pm 0.16$ & $4.25 \pm 0.16^{*}$ & $2.75 \pm 0.31^{*} *$ & $3.13 \pm 0.23^{* *}$ & $3.63 \pm 0.25$ \\
\hline $\mathrm{pH}$ & $6.14 \pm 0.24$ & $8.14 \pm 0.38^{*}$ & $6.64 \pm 0.24$ & $7.14 \pm 0.24$ & $7.07 \pm 0.35$ \\
\hline $\mathrm{t}^{0} \mathrm{C}$ & $37.47 \pm 2.36$ & $38.87 \pm 1.59$ & $37.64 \pm 3.36$ & $37.91 \pm 1.28$ & $38.09 \pm 2.24$ \\
\hline
\end{tabular}

Note: $*$ - significant in relation to IC ( $p \leq 0.05) ; * *-$ significant in relation to control pathology $(p \leq 0.05)$ $* * *-$ significant in relation to $C P+$ Gravagin $(p \leq 0.05)$

Thus, under the influence of suppositories "Melanizol", normalization of ESR and reduction to almost intact level of the number of leukocytes was observed, as well as restoration of indicators of leukocyte formula in animals. Improvements in hemoglobin and erythrocyte counts were observed in the $\mathrm{CP}$ group. Compared to suppositories of "Melanizol", the suppositories of "Gravagin" were significantly superior to the comparison drug "Hippophaes oleum suppositories" on the experimental model of mechanical vaginitis.

Macroscopic studies of the VM of rats of the CP group (Table 3 ) on the $11^{\text {th }}$ day of the experiment also confirmed the development of experimental "mechanical" vaginitis: the area of the affected vagina was $71.18 \%$ of the total area, edema, hyperemia and numeri- cal hemorrhages were reflected in integrable characteristics and amounted to 7.71 points.

The study of VM (Table 3 ) of rats on the $11^{\text {th }}$ day shows a significant reduction in the area of the affected vaginal area in rats under the influence of "Melanizol" suppositories compared to the CP group. The suppressive effect on the course of local inflammation in the "mechanical" vaginitis of the studied and reference drugs also manifested in a reliable, in relation to the $\mathrm{CP}$ group, reduction of the intensity of edema, hyperemia and the number of hemorrhages by the integral indicator of the state of VM - sum of points "Hippophaes oleum suppositories" in 2.34 times, suppositories of "Gravagin" in 1.68 times. 
Influence of the research agents on the state of SOP rats on the background of "mechanical" vaginitis on the $11^{\text {th }}$ day of the experiment $\left(\mathrm{n}=7, \mathrm{x} \pm \mathrm{S}_{\mathrm{x}}\right)$

\begin{tabular}{|c|c|c|c|c|c|}
\hline \multicolumn{2}{|r|}{ Indicator } & $\mathrm{CP}$ & CP+Melanizol & CP+Hippophaes & $\mathrm{CP}+$ Gravagin \\
\hline \multicolumn{2}{|c|}{$\begin{array}{l}\text { The total area of the vagina, } \\
\mathrm{mm}^{2}\end{array}$} & $\underline{247.86 \pm 18.67}$ & $\underline{175.86 \pm 13.49}$ & $\underline{265.86 \pm 20.19}$ & $\underline{267.50 \pm 9.78}$ \\
\hline \multicolumn{2}{|c|}{$\begin{array}{l}\text { The total area of the affected } \\
\text { vagina, } \mathrm{mm}^{2}\end{array}$} & $\underline{160.38 \pm 9.43}$ & $\underline{54.13 \pm 5.91 * / * *}$ & $71.42 \pm 11.28^{*}$ & $78.00 \pm 5.52 *$ \\
\hline \multicolumn{2}{|c|}{$\begin{array}{l}\text { The total area of the affected } \\
\text { vagina, } \%\end{array}$} & $63.37 \pm 5.05$ & $21.77 \pm 2.49^{*}$ & $27.10 \pm 5.41^{*}$ & $29.42 \pm 2.33^{*}$ \\
\hline \multirow{4}{*}{ 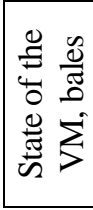 } & Edema & $2.75 \pm 0.16$ & $1.38 \pm 0,26$ & $1.71 \pm 0,31$ & $1.63 \pm 0,26$ \\
\hline & Hyperemia & $2.00 \pm 0.33$ & $0.87 \pm 0,23$ & $1.00 \pm 0,27$ & $1.00 \pm 0,27$ \\
\hline & $\begin{array}{l}\text { Intensity of hemor- } \\
\text { rhages }\end{array}$ & $2.38 \pm 0.18$ & $0.63 \pm 0.18$ & $0.75 \pm 0.16$ & $0.75 \pm 0.16$ \\
\hline & Sum of points & $7.13 \pm 0.58$ & $2.88 \pm 0.35^{*}$ & $3.37 \pm 0.53 *$ & $3.37 \pm 0.53 *$ \\
\hline
\end{tabular}

Note: $*$ - significant in relation to $C P(p \leq 0.05) ; * *$ - significant in relation to $C P+$ Gravagin $(p \leq 0.05)$

Thus, the obtained data indicate that therapeutic effect of "Melanizol" suppositories suppositories on the "mechanical" vaginitis comparable in effectiveness with "Hippophaes oleum suppositories" and superior to the suppositories of "Gravagin".

\section{Discussion of the research results}

After systematizing the results was shown the therapeutic effect of the suppositories of "Melanizol" on the level of reference drug - "Hippophaes oleum suppositories" on the background of vaginitis was also shown by the stabilization of trophic processes.

Suppositories of "Melanizol" normalize high level of ESR and reduce level of the number of leukocytes, restore of indicators of leukocyte formula, show antiinflammatory effect on the model of "mechanical" vaginitis in animals $[13,14]$.

The obtained data during the experiment indicate that the pathology was accompanied by an increased temperature, confirming the presence of an inflammatory reaction, and a significant shift of the $\mathrm{pH}$ toward the alkali of the environment in the vagina of animals of the CP group compared with IC [15] and the development of pathogenic microflora [16]. Against the background of treatment with suppositories "Melanizol" there is a restoration of $\mathrm{pH}$ and temperature in the vagina of animals, which testifies to their anti-inflammatory and antimicrobial effect.

Influence of suppositories "Melanizol" on the experimental "mechanical" vaginitis in rats was significantly positive, reducing the signs of acute inflammation in the case of pathology of NV. This can be explained by the presence in the investigated suppositories of "Melanizol" tea tree oil, which according to the literature has an anti-inflammatory effect in the conditions of experimental pathology [17], by terpinen-4-ol which inhibits lipopolysaccharide-induced formation of mediators of inflammation tumour necrosis factor alpha (TNF- $\alpha$ ), interleukin-1 $\beta$ (IL-1 $\beta$ ) and IL-10 by monocytes and prostaglandin $\mathrm{E}_{2}[18,19]$.

Study limitations. Studies of the therapeutic effects of new vaginal suppositories "Melanizol" based on metronidazole and tea tree oil on the model of "mechanical" vaginitis in female rats have shown the presence of their anti-inflammatory action. In addition, it proved the perspective of further study of suppositories of "Melanizol" for the treatment of non-specific vaginitis caused by mechanical irritant.

Prospects for further research. The aim of the work was a study using new vaginal suppositories of "Melanizol" for the treatment of vaginitis. The next stage is to study the mechanisms of action of components of the suppositories of "Melanizol" methanidazole and tea tree oil in experimental vaginitis.

\section{Conclusions}

Thus, the study shows that the suppositories of "Melanizol" had a therapeutic effect in the conditions of "mechanical" vaginitis in rats, which was manifested by a reliable restoration of the $\mathrm{pH}$ and the temperature in the vagina of animals, reducing the rate of erythrocyte sedimentation and total leukocyte count, level of neutrophils to indicators of the group of intact animals and improvement of the vaginal mucosa. The expressiveness of therapeutic action is not inferior to the drug of comparison "Hippophaes oleum suppositories" and surpassed the comparison drug suppositories of "Gravagin".

Thus, vaginal suppositories "Melanizol" are perspective drug for the further studies as medication for the treatment of vaginitis caused by mechanical irritant.

\section{Conflict of interests}

Authors declare no conflict of interests

\section{References}

1. De Seta, F., Campisciano, G., Zanotta, N., Ricci, G., Comar, M. (2019). The Vaginal Community State Types Microbiome-Immune Network as Key Factor for Bacterial Vaginosis and Aerobic Vaginitis. Frontiers in Microbiology, $10,2451$. doi: http://doi.org/10.3389/fmicb.2019.02451

2. La Vignera, S., Condorelli, R. A., Cannarella, R., Giacone, F., Mongioi', L. M., Cimino, L. et. al. (2019). Urogenital infections in patients with diabetes mellitus: Beyond the conventional aspects. International Journal of Immunopathology and Pharmacology, 33. doi: http://doi.org/10.1177/2058738419866582 
3. Superti, F., De Seta, F. (2020). Warding Off Recurrent Yeast and Bacterial Vaginal Infections: Lactoferrin and Lactobacilli. Microorganisms, 8 (1), 130. doi: http://doi.org/10.3390/microorganisms 8010130

4. Olina, A. A., Meteleva, T. A. (2016). Current possibilities in the treatment of non-specific vaginal infectious diseases. Rossiiskii Vestnik Akushera-Ginekologa, 16 (6), 89-94. doi: http://doi.org/10.17116/rosakush201616689-94

5. Yarnykh, T. H., Levachkova, Yu. V., Maloshtan, L. M., Stepanova, K. O. (2011). Pat. 96646 UA. Protyzapalnyi zasib u formi pesariiv z metronidazolom i oliieiu chainoho dereva. No. a 201001134; declareted: 04.02.2010; published: 25.11.2011. Bul. No. 22,3 .

6. Kompendium. Likarski preparaty. Available at: https://compendium.com.ua/uk/

7. Dolzhykova, O. V., Maloshtan, L. M. (2014). Eksperymentalne vyvchennia protyzapalnykh vlastyvostei novykh supozytoriiv vahinalnykh "Melanizol". Problemy ekolohichnoi ta medychnoi henetyky i klinichnoi imunolohii, 4 (124), $161-166$.

8. Dolzhykova, O. V., Maloshtan, L. N. (2016). Microbiological predication of using of vaginal suppositories "melanizol" for treatment nonspecific vaginitis. Ukrainian biopharmaceutical journal, 3 (44), 20-23. doi: http://doi.org/10.24959/ubphj.16.34

9. Drogovoz, S. M., Cypkun, A. G., Reshetniak, V. V., Derimedved, L. V., Kartashevskaia, R. A. (2003). Metody eksperimentalnogo izucheniia biologicheski aktivnykh veschestv na modeliakh vulvovaginita. Kyiv, 19.

10. European convention for the protection of vertebral animals used for experimental and other scientific purpose. Council of Europe 18.03.1986. (1986). Strasbourg, 52.

11. Rybolovlev, Iu. R., Rybolovlev, R. S. (1979). Dozirovanie veschestv dlia mlekopitaiuschikh po konstantam biologicheskoi aktivnosti. Doklady AM SSSR, 247 (6), 1513-1516.

12. Kamyshnikov, V. S. (2009). Spravochnik po kliniko-biokhimicheskim issledovaniiam i laboratornoi diagnostike. Moscow: MEDpressinform, 889.

13. Tansarli, G. S., Kostaras, E. K., Athanasiou, S., Falagas, M. E. (2013). Prevalence and treatment of aerobic vaginitis among non-pregnant women: evaluation of the evidence for an underestimated clinical entity. European Journal of Clinical Microbiology \& Infectious Diseases, 32 (8), 977-984. doi: http://doi.org/10.1007/s10096-013-1846-4

14. Savicheva, A. M., Tapilskaya, N. I., Shipitsyna, E. V., Vorobyeva, N. E. (2017). Bacterial vaginosis and aerobic vaginitis as major vaginal microflora balance disorders: Diagnostic and therapeutic characteristics. Akusherstvo i Ginekologiia, 5, 24-31. doi: http://doi.org/10.18565/aig.2017.5.24-31

15. Krasnonos, K. M. (2017). Vplyv bakterialnoho vahinozu na perebih vahitnosti. Sumy, 89.

16. Nasioudis, D., Beghini, J., Bongiovanni, A. M., Giraldo, P. C., Linhares, I. M., Witkin, S. S. (2015). $\alpha$-Amylase in Vaginal Fluid: Association With Conditions Favorable to Dominance of Lactobacillus. Reproductive Sciences, 22 (11), $1393-1398$. doi: http://doi.org/10.1177/1933719115581000

17. Politun, A. M., Venger, E. A. (2010). Novye gigienicheskie sredstva ukhoda za polostiu rta. Endodontist, 2 (4), 1-4.

18. Hart, P. H., Brand, C., Carson, C. F., Riley, T. V., Prager, R. H., Finlay-Jones, J. J. (2000). Terpinen-4-ol, the main component of the essential oil of Melaleuca alternifolia (tea tree oil), suppresses inflammatory mediator production by activated human monocytes. Inflammation Research, 49 (11), 619-626. doi: http://doi.org/10.1007/s000110050639

19. Carson, C. F., Hammer, K. A., Riley, T. V. (2006). Melaleuca alternifolia (Tea Tree) Oil: a Review of Antimicrobial and Other Medicinal Properties. Clinical Microbiology Reviews, 19 (1), 50-62. doi: http://doi.org/10.1128/cmr.19.1.50-62.2006

Received date 08.01.2020

Accepted date 30.01.2020

Published date 29.02.2020

Olena Dolzhykova, $\mathrm{PhD}$, Associated of Professor, Department of Clinical Laboratory Diagnostics, National University of Pharmacy, Pushkinska str., 53, Kharkiv, Ukraine, 61002

E-mail: dolzhikova.elena20@gmail.com

Ludmila Maloshtan, Doctor of Biological Sciences, Professor, Head of Department, Department of Physiology and Human Anatomy, National University of Pharmacy, Pushkinska str., 53, Kharkiv, Ukraine, 61002

E-mail: lnm004@gmail.com 